\title{
Early Childhood Development Trainee Teachers' Perceptions on E- learning Implementation during the COVID-19 era in Harare Metropolitan District, Zimbabwe
}

\author{
Melody Matsvange ${ }^{1}$, Jonah Mugomba ${ }^{2}$, Silas Sithole $^{3}$, Address Murumbi ${ }^{4}$ \\ ${ }^{I}$ Great Zimbabwe University, School of Education and Culture, Department of Educational \\ Foundations, ECD Section, Masvingo, Zimbabwe \\ ${ }^{2}$ Great Zimbabwe University, School of Education and Culture, Department of Educational \\ Foundations, ECD Section, Masvingo, Zimbabwe \\ ${ }^{3}$ Great Zimbabwe University, School of Education and Culture, Department of Technical Education, \\ Masvingo, Zimbabwe \\ ${ }^{4}$ Ministry of Primary and Secondary Education, Infant Department, Harare, Zimbabwe
}

\begin{tabular}{|c|c|}
\hline Artic & Abstract \\
\hline $\begin{array}{l}\text { Article history: } \\
\text { Received: } 26 \text { May } 2021 \\
\text { Revised: } 21 \text { July } 2021 \\
\text { Accepted: } 22 \text { July } 2021\end{array}$ & $\begin{array}{l}\text { Purpose: The study aimed at finding out the extent to which Early } \\
\text { Childhood Development }(E C D) \text { trainee teachers perceive the feasibility and } \\
\text { challenges of online learning platforms and generate strategies for effective } \\
\text { implementation. }\end{array}$ \\
\hline $\begin{array}{l}\text { Keywords: } \\
\text { Online Learning, } \\
\text { Feasibility, } \\
\text { ECD, } \\
\text { Students, } \\
\text { Higher Learning Institutions. }\end{array}$ & $\begin{array}{l}\text { Approach/Methodology/Design: A case study design for which fifteen ECD } \\
\text { trainee teachers from two Higher Learning Institutions in Harare were } \\
\text { purposively selected in this qualitative study through online structured } \\
\text { questionnaires and telephone interviews expressed in English. Data } \\
\text { gathered was expanded in thick rich descriptions to form themes. }\end{array}$ \\
\hline $\begin{array}{l}\text { Paper Type : } \\
\text { Research Article }\end{array}$ & $\begin{array}{l}\text { Findings: Innumerable benefits of e-learning were established. E-learning } \\
\text { facilitates the continuation of learning, motivates, improves student-to- } \\
\text { student interaction, is a convenient way of submitting assignments, reduces } \\
\text { commutation and material costs and is an easy way of storing documents. }\end{array}$ \\
\hline Corresponding Author: & $\begin{array}{l}\text { However various setbacks were elucidated. Erratic power cuts and internet } \\
\text { failures, exorbitant costs of data bundles and lack of smart devices deter the }\end{array}$ \\
\hline Melody Matsvange & full embracing of e-learning. \\
\hline $\begin{array}{l}\text { Email: } \\
\text { mmatsvange@gzu.ac.zw }\end{array}$ & $\begin{array}{l}\text { Practical Implications: Zimbabwean HLIs have adjusted to the new normal } \\
\text { and embraced online learning to ensure the continuation of learning in the } \\
\text { midst of the pandemic. Online learning overcomes educational obstacles }\end{array}$ \\
\hline $\begin{array}{l}\text { ORCID ID: } \\
\text { https://orcid.org/0000-0003- } \\
\underline{4613-9078}\end{array}$ & $\begin{array}{l}\text { and students will not only follow courses using the traditional method. } \\
\text { Originality/value: The findings suggest trainee teachers require the } \\
\text { provision of cheap data bundles, free internet applications and extension of } \\
\text { due dates. The use of blended approach/hybrid learning to assist those in } \\
\text { remote communities, training workshops and seminars on effective use of e- } \\
\text { learning platforms were deemed essential. }\end{array}$ \\
\hline
\end{tabular}

1. Introduction

The restrictions and lockdowns induced by the novel Coronavirus has made learning institutions worldwide take an intensive measure to curb the spread of the disease and protect students by moving out of "brick and mortar" classrooms to e-learning thus ensuring the 
continuation of learning in this COVID-19 era. At no circumstance has the world evidenced educational interruption on such an enormous scale. The disruption in the education system by Coronavirus (COVID-19) has impacted over $90 \%$ of the student population of the world (UNESCO, 2020). COVID-19 has spread speedily worldwide sending billions of people into lockdown. The pandemic as declared by WHO has thrown the global academic calendar into a state of disarray. The situation in most higher learning institutions changed drastically in the spring semester of 2020 causing immediate closure of universities and schools. Some students and parents self-quarantined themselves at their homes to curb the spread of the disease. Universities and colleges took intensive measures to prevent and protect all students and staff members from highly infectious disease (Nagar 2020; Demaykor, 2020). As a mitigation measure to the impact of Coronavirus, the education sector has shifted from the historical chalkboard face-to-face teaching to online modes of teaching within a short period to grapple with the demands of the curriculum and students' needs.

A study by Allo (2020) highlighted that 233 million students were not at school due to the virus across China including Hong Kong and Macao-specific administration areas, followed by the Japanese, which had nearly 16.5 million students who were moved out of school. A study by Bao (2020) airs that due to the widespread of Coronavirus disease (COVID-19) in China, most Chinese universities have started online education following the government's requirements of non-stop teaching and learning.

Most continents such as Asia, Europe, Middle East, North America South America and Africa have announced or implemented school and university closures. As of March 25, 2020, 150 countries closed schools and educational institutions worldwide, impacting over $80 \%$ of the world's student population (Sahu, 2020). Adotey (2020) highlights that universities across Africa, including the ones in countries such as Egypt, Ghana, South Africa, and Rwanda among others have moved some of their programs to online platforms and partnered with Telco's to zero-rate these platforms. In Zimbabwe, all face to face teaching and learning process was suspended from 24 March 2020 following the recommendation by his Excellency Emmerson Dambudzo Mnangagwa who announced a state of emergency. The Zimbabwean government ordered all educational institutions to stop face-to-face lectures on campuses immediately and proceed with e-learning as a safety measure to protect students and staff from a sudden spike in the number of cases of COVID19 (Mukeredzi \& Mashininga, 2020; Dzenga 2020; Herald, 2020).

A study in Indonesia established that some universities in that region were very responsive in taking steps related to the prevention of COVID-19 transmission by eliminating activities on their campuses in the middle of pandemic (Allo, 2020). In the same footsteps, Zimbabwean universities also embraced alternative modes of delivering content through online platforms (Dzenga, 2020). Education across the globe took a new trajectory and it was incumbent upon universities and other learning institutions to embrace new learning methods and enhance access to education (Herald, 2020).

However, change disrupts comfort and mostly creates situations filled with anxiety and uncertainties among the change recipients (Issah, 2018). Students in higher learning 
institutions developed different sentiments on the feasibility of online learning in Zimbabwe. Tertiary students were reported to be up in arms against their institutions over online learning which universities adopted and the Zimbabwean national student representatives across all higher learning institutions echoed sentiments that accessing online learning portals was difficult and expensive for most learners (Newsday, 2020).

\section{Literature Review}

COVID 19 pandemic has forced many structures including the education structure into lockdown. Educational stakeholders had to adjust to this new normal and deliver lessons virtually to enable continuity in learning. In a bid to have a substantial foundation on the perceptions of ECD trainee teachers at higher learning institutions in the implementation of elearning, the keystone of the study is a theory by Linda Harasim called online collaborative learning (OCL). The theory focuses on the internet as a source of learning through fostering collaboration and the building of knowledge (Demuyakor, 2020). OCL is believed to support three phases of knowledge acquisition and construction which include idea-generating, idea organizing and intellectual convergence which trainee teachers will acquire as they learn online. Demuyakor (2020) deliberates that idea organizing is whereby different ideas are compared, analyzed, and put into a category using organized discussions and arguments, intellectual convergence is a phase whereby intellectual synthesis and consensus take place. Agreeing to disagree is embraced; assignments are made in the form of essays as well as joint pieces of work (Harasim, 2017). The main characteristic of OCL is that the work of a teacher is to facilitate the process of learning unlike in other theories.

\section{E-learning Policies in Zimbabwe}

Madi (2015) states that the Zimbabwean government adopted a National Information and Communication Technology (ICT) Policy in 2005 which seeks to transform Zimbabwe into a knowledge-based society by 2020 and to accelerate the development and application of elearning in support of economic growth and development. Other policies which include Vision 2020 the National Science and Technology policy 2002 and Nziramasanga Education Commission Report (1999) recommended the promotion of the educational use of computers for teaching and learning in educational institutions. Furthermore, Zimbabwe is one of the 10 countries involved in Africa's institutions of higher learning a teacher education project established by the African Virtual University (AVU) (Isaacs, 2007; Maruti, 2010). AVU quests to offer training to academicians in African universities thereby ensuring development of teachers in colleges and universities. However, before this COVID-19 era which has forced the embracing of online learning the ICT policy recommendations were not effectively implemented.

\section{E-Learning Platforms}

E-learning or online learning comes in several ways which are knowledge base, online support, asynchronous training, synchronous training or hybrid. Knowledge base type is a set of lessons that are published on the website and have general instructions of learning that a 
student has to follow with no support (Basilaia \& Kvavadze, 2020). Online support is a modified version of the knowledge base where the support is available to get support on some topics (Nagar, 2020). Asynchronous training is the one where the lessons do not take place in real-time, but students are provided with content regularly. The advantage of asynchronous learning is the possibility of an individualized pace, place and intensity of learning (Gorska, 2016). Fully online learning is asynchronous, the tools that are employed in this form of learning include databases, document libraries, e-books, forums, messaging, emails, streaming audio \& video, Blogs and website links (Nagar, 2020). Synchronous training has a pre-set time to log-in to the online education environment and participants can communicate directly with the teacher and other group members (Gorska, 2016). Web-assisted mode of elearning uses synchronous tools, wherein, to enhance teaching and make learning effective the course website and well-designed tools are used (Nagar, 2020). Hybrid training/blended learning is a combination of online and in-person interaction (Basilaia \& Kvavadze, 2020). Therefore, teaching/ learning is done both online and some concepts are taught face to face in hybrid learning.

\section{Benefits of e-learning}

There are numerous benefits of using online learning. Students can receive lecture notes electronically within a second. Madi (2015) airs that through e-learning also, the old method of teaching for long hours facing hundreds of students has been eliminated. E-learning more than any other technology provides lecturers and students access to vast stores of knowledge beyond the college, as well as with multi-media tools to add to this store of knowledge (UNESCO, 2011). The huge growth of computers, the internet and other electronic devices provide global opportunities for education, especially for learning outside the premises of the school (Ngwoke \& Numonde, 2011).

Furthermore, e-learning offers the flexibility and convenience to complete learning units when and where a student's desires. Students use the Internet to make learning choices more diverse and personalized, to make learning content and activities freer, and to make information technology and teaching more closely (Zhou, Li, Wu \& Ming Zhou, 2020). The most attractive feature of e-learning is that it is student-centered and it accommodates individual preferences and needs (Wani, 2013). This means that it empowers students of various backgrounds to have equal access to the best resources and referral material, lecture sessions, tutoring, and experienced teachers.

The format allows students to learn easily for the standardized tests by downloading the study material they want, rather than paying hefty bills to tuition. In addition to potential cost savings, e-learning has pedagogical potential beyond traditional methods related to the principles of learning discussed (The Pay-offs 2003; Nagar 2020). E-learning can deliver "new" information not contained in traditional sources, effectively reinforcing other course information through offering examples, explanations, assessments, and exercises. In this way, online instruction can potentially enhance learning compared to what can be attained using a traditional approach as it allows host live classes on any topic. 


\section{Insights of students towards online learning}

Although e-learning continues to grow rapidly, it remains at an early stage of development. Consequently, developers and deliverers of online learning need more understanding of how students perceive and react to elements of e-learning (since student perception and attitude is critical to motivation and learning) along with how to apply these approaches most effectively to enhance learning (Koohang \& Durante, 2003). Students certainly have their perception of online learning and it is an input for lecturers and institutions in running this online learning process to avoid teething problems. The evaluation of e-learning readiness can be done from (a) the point of view of its various stakeholders (students, teachers, elearning experts/lab administrators or (b) the point of view of various technological organizational, environmental, nature of courses offered (Kaur and Abas, 2004). From the perspective of stakeholders, most of the times faculty members perceive e-learning to be positive and useful (Nagar, 2020). The majority of the students also perceived that e-learning is useful and effective (Fageeh, 2011). On the contrary they also had many issues which reduced their readiness towards e-learning (Fathimath, 2016). Studies also showed that student's satisfaction was less in e-learning platforms than in traditional systems or they were still not ready for e-learning (Fathimath, 2016).

Popovici and Mironov (2014) found out that it becomes quite obvious that students are deeply aware of the changes brought over by the digital technologies, by their impact on the learning process. Related to a gender perspective, Keller and Cernerud (2002) show that male students, students with previous knowledge of computers and students with positive attitudes to new technologies were all less positive to e-learning on campus than other students. Eldeeb (2014) investigate that student's preferred mixed-mode and web supplemented courses rather than a web-dependent course or fully online courses. A study by Allo (2020) which investigated the English learner's perception amid COVID-19 pandemic revealed online learning is good and very helpful in such times of a pandemic.

Smart and Cappel (2006) examined learners' perceptions of integrating online components in two undergraduate business courses where learners completed online learning modules before class discussion. The results indicate that participants in an elective course rated the online modules significantly better than those in a required course. Overall, participants in the elective course rated the online modules marginally positive while those in the required course rated them marginally negative (Allo, 2020)

\section{Challenges of e-learning platforms}

The adoption of e-learning has been hampered by a number of challenges that have negatively affected its full-scale adoption, utilization and optimization (Kasse \& Balunywa, 2013; Rumble 2001). Some of the most significant constraining factors as being limited bandwidth, followed by the lack of financial resources, inadequate human resource capacity and limited electricity (The e-learning Africa Report 2012; Isaacs 2002; Zhou, Li, Wu \& 
Ming Zhou, 2020). Most families in disadvantaged communities do not own computers or smartphones thus having a negative impact on the whole online education (Basilaia \& Kvavadze, 2020). Learners and students from such communities lack the devices and internet access to be able to participate in online classes, and most schools do not have the capacity to teach online.

Attitudinal factors like perceived ease of use of e-learning, perceived usefulness of e-learning and availability (Abdel- Wahab, 2008). Some research studies have shown that the lack of knowledge and attitude of faculty members in the field of information and communication technology (ICT) is one of the major limitations of using e-learning in the classroom. Many students struggle to follow up internet lessons in homes where power cuts and mobile internet data bundles are pricey (Natsai \& Mwayera, 2020). A report compiled in 2019 evidence that the Zimbabwean mobile internet is the most expensive in Sub Sahara Africa (Dzenga, 2020). Similarly, Tamrat and Teffera (2020) highlighted that going online is not that simple on a continent where only $24 \%$ of the population has access to the internet and poor connectivity, exorbitant costs and frequent power interruptions are serious challenges.

A study by Sahu (2020) mentions that the transition from face-to-face teaching to online delivery has a serious impact on assessments and evaluation. Although technology has been used earlier to support teaching and learning, the assessment aspect is often under-developed (Timmis, Broadfoot, Sutherland \& Oldfield, 2016). Other potential problems of e-learning that have been identified in previous research include a sense of learner isolation (Brown, 1996); learner frustration, anxiety, and confusion: higher student attrition rates (Laine, 2003): the need for grate discipline, writing skills, and self-motivation: and the need for online to make time commitment to learning (Serwatka, 2003).One study concluded that asynchronous e-learning was not effective as a standalone method to deliver technical training for information technology professionals (Nagar, 2020). Learners in the study commented that elearning eliminates classroom interaction time where a significant amount of "real learning" takes place as users assimilate information, utilize software, apply knowledge to problemsolving and interact with the instructor and other learners (Laine, 2003).

\section{Strategies for effective implementation}

E-learning has great potential in HLIs. Therefore, to maximize this potential, its implementation should attempt to satisfy the needs and concerns of ECD trainee teachers as much as possible. Students and instructors should participate as proactively as possible, provide feedback to improve future experiences, and communicate the learning possibilities that e-learning creates (Wani, 2013). Institutions should provide the technical infrastructure and support needed to enable comprehensive solutions.

Sun and Chen (2016) provide practical suggestions for those who are planning to develop online courses so that they can make informed decisions in the implementation process. Based on the findings, the authors argued that effective online instruction is dependent upon 1) well-designed course content, motivating interaction between the instructor and learners, well-prepared and fully-supported instructors; 2) creation of a sense of online learning 
community; and 3) rapid advancement of technology. Hence, the use of a voice note application on the WhatsApp application to provide instructions to students is pivotal to make e-learning feasible.

In addition, the use of group task is essential to help students who do not have access to the internet, internet data, or damaged network. Group tasks on online learning system in accordance with the learners is to help friends who do not have an internet pulse (Demuyakor, 2020). Group tasks help to exchange thoughts. Moreover, lecturers should also extend deadlines for assignment submission to curb the challenge of network. Zimbabwean universities also extended deadlines for assignment submissions and advised students through circulars in student portals not to be compelled to the due dates earlier set before the pandemic.

Acceptance ability in terms of understanding of learning problems is very different (Demuyakor, 2020). Some students understand better if there is material explanation first, before tasks and to others the opposite is true. When soft-copy materials are sent to students, and if some fail to grasp the concepts then clarity will be sought through WhatsApp platforms (Demuyakor, 2020). E-learning platforms such as Google Classroom, Moodle, and Google Meet seem far reached and burdensome to those trainee teachers who rely on their financial ability to work to study. Tamrat and Teferra (2020) propound that increasingly universities are partnering with internet providers and governments to cover this critical challenge by negotiating zero related access to specific educational and informative websites as in the case of Rwanda, South Africa and Tunisia. Making use of free and less costly applications such as Messenger or WhatsApp assists in making e-learning flow. In addition, it is essential to create learning groups in Messenger so that friends who do not have internet packages can get information.

Having looked at the various e-learning platforms, benefits, challenges of using online learning platforms, e-learning guiding frameworks and possible strategies for effective implementation, it is imperative that lecturers, trainees and all the other concerned stakeholders join hands to make e-learning work. Pandemics and natural disasters will always disrupt the different aspects of our lives hence shifting mindsets and embracing the alternative methods of teaching and learning is the best option to choose.

\section{Methodology and Procedures}

This case study aimed at finding out the ECD trainee teachers' perceptions on the implementation of E-learning in Harare Metropolitan during the COVID-19 era. A case study is a variation of an ethnography in that the researcher provides an in-depth exploration of a bounded system based on extensive data collection (Creswell 2007).

\section{Participants}

Of the multiple HLIs institutions which offer ECD programmes in Harare Metropolitan District, two institutions were purposively sampled to have a representation of trainee 
teachers undertaking ECD programmes at different levels. The 2 institutions' statistics indicate that they have a total of 650 ECD students and these which formulated the population for this study. However, time and financial constraints delineated the number of participants for this study. Purposive sampling was used to select the participants and 15 ECD trainee teachers formed the sample. Thus 6 ECD trainee teachers were selected from those in the Master of Education in ECD (MECD) Programme, 6 from the Bachelors of Education in ECD (BECD) and 3 from the Diploma of Education in ECD (DECD).

\section{Instruments}

Data was obtained through primary sources which are online structured questionnaires and interviews which were all expressed in English and Shona language. The response rate was $100 \%$.

\section{Online Questionnaires and Interviews}

Questionnaires were distributed through WhatsApp and Email to 3 diploma in ECD trainee teachers and $6 \mathrm{BECD}$ trainee teachers. Online questionnaires were deemed appropriate for this research because data collection was done observing the COVID-19 restrictions in trying to curb the spread of Coronavirus. 6 MECD teacher trainees were interviewed through WhatsApp Call Application thus reducing telephone costs and online interviews were settled for because of their flexibility in the language of communication. The researchers used Shona and English languages to interact with the participants, according to their convenience. Cohen and Marion (2011) explain that one can use a language that the specific respondent prefers most. Thematic analysis was applied to analyze the data. Braun and Clarke (2006) defines thematic analysis as an iterative process as to how to go from messy data to a map of the most important themes in the data.

\section{Results and Discussion}

\section{Gender Distribution}

Table 1: Results on Gender of Participants

\begin{tabular}{|l|l|l|l|l|}
\hline Respondents & Male & Female & Total & \% \\
\hline Diploma in ECD trainee teachers & 0 & 3 & 3 & $20 \%$ \\
\hline $\begin{array}{l}\text { Bachelor in ECD trainee } \\
\text { teachers }\end{array}$ & 2 & 4 & 6 & $40 \%$ \\
\hline Masters in ECD trainee teachers & 3 & 3 & 6 & $40 \%$ \\
\hline Total & $\mathbf{5}$ & $\mathbf{1 0}$ & $\mathbf{1 5}$ & $\mathbf{1 0 0 \%}$ \\
\hline Percentage & $\mathbf{3 3 , 3 \%}$ & $\mathbf{6 6 , 7 \%}$ & $\mathbf{1 0 0 \%}$ & \\
\hline
\end{tabular}

Source: Author

Interpreting from Table 1 overleaf, more female students fell in the sample as popularly many females pursue education professions. Males were 33, 3\% while females were $66,7 \%$. Therefore it can be proved that female students composed the major part of the participants.

\section{Age Distribution}


Table 2. Age of Respondents

\begin{tabular}{|l|l|l|l|l|l|l|l|l|l|l|l|}
\hline & $19-29 y r s$ & \multicolumn{3}{|c|}{$30-39 y r s$} & $40-49 y r s$ & \multicolumn{3}{|c|}{ Above 50yrs } \\
\cline { 2 - 14 } & $\mathrm{M}$ & $\mathrm{F}$ & $\mathrm{M}$ & $\mathrm{F}$ & $\mathrm{M}$ & $\mathrm{F}$ & $\mathrm{M}$ & $\mathrm{F}$ & Total & $\%$ \\
\hline Diploma of Education in ECD & 0 & 2 & 0 & 1 & 0 & 0 & 0 & 0 & 3 & 20 \\
\hline Bachelor of Education in ECD & 0 & 1 & 1 & 2 & 1 & 1 & 0 & 0 & 6 & 40 \\
\hline Master of Education in ECD & 0 & 1 & 2 & 0 & 1 & 1 & 0 & 1 & 6 & 40 \\
\hline Total & $\mathbf{0}$ & $\mathbf{4}$ & $\mathbf{3}$ & $\mathbf{3}$ & $\mathbf{2}$ & $\mathbf{2}$ & $\mathbf{0}$ & $\mathbf{1}$ & $\mathbf{1 5}$ & $\mathbf{1 0 0}$ \\
\hline Percentage \% & $\mathbf{0}$ & $\mathbf{2 6 . 7}$ & $\mathbf{2 0}$ & $\mathbf{2 0}$ & $\mathbf{1 3 . 3}$ & $\mathbf{1 3 . 3}$ & $\mathbf{0}$ & $\mathbf{6 . 7}$ & $\mathbf{1 0 0}$ & \\
\hline
\end{tabular}

Source: Author

Table 2 illustrates the age ranges and sex of the respondents. The data revealed that $26,7 \%$ belonged to the 19-29 year age group, $40 \%$ were between $30-39$ years, $26,6 \%$ belonged to the 40-49 years range and only 6,7\% of participants were above 50 years old. From the above table, it can be interpreted that the majority of the respondents fell in the 30-39 years age range and the male and female respondents in this range are mature enough and still active to embrace new technological advancements in their learning.

\section{Professional Qualifications}

Table 3: The following table shows professional qualifications of respondents

\begin{tabular}{|l|l|l|}
\hline Department & Frequency & Percentage \% \\
\hline Diploma of Education in ECD & 3 & 20 \\
\hline Bachelor of Education in ECD & 6 & 40 \\
\hline Master of Education in ECD & 6 & 40 \\
\hline Total & $\mathbf{1 5}$ & $\mathbf{1 0 0}$ \\
\hline
\end{tabular}

N 15

Source: Author

Table 3 above show that the minority (20\%) of the respondents were pursuing Diploma in ECD. Accordingly, $40 \%$ of students were pursuing BECD, similarly, $40 \%$ were pursuing MECD. This shows that there was equal representation of students in MECD and BECD meaning that there was no effect on the outcome since the study assumed that students have different perceptions.

\section{Discussion}

Theme 1 sought to find students perceptions on e-learning amid the COVID-19 pandemic. Research findings indicated that ECD trainee teachers' perceived e-learning as appropriate and effective amid COVID-19 pandemic. In line with Popovici and Mironov (2014) students are deeply aware of the changes brought over by the digital technologies and the impact on the learning process. However the present study is different with Keller and Cernerud (2002) that students did not regard access to e-learning on campus as a benefit. As research findings indicated that both male and female students were in favor of e-learning and highlighted it is very easy to type and sent assignments via email and can communicate with their pals through video conference or Skype whilst they are doing school work. 
Regarding theme 2 which attempted to reveal the effectiveness of e-learning amid COVID pandemic. Respondents exposed a vast of e-learning benefits which were similar to those in literature. This is quite different from Newsday (2020) which reports that tertiary students are up in arms against their institutions over online learning which universities have adopted as it is too expensive.

Theme 3 endeavored to highlights the challenges of using E-learning by HLIs students in the midst of COVID -19 pandemic. From the collected data, students do not have smart devices, expose social difference, no internet access due to erratic power supply and lack of access by learners with disabilities, failure to meet due dates and failure to understand instructions and lack of expertise in using the internet applications. Mamattah (2016) shares a similar view that the majority of the respondents think it is more expensive to offer courses through elearning than fully face-to-face learning. It can be deduced that if decisions about choice of learning mode were to be made based on cost most of the respondents will go for fully classroom learning than e-learning if all the challenges are not addressed. Contrary a study by Mislinawati and Nurmasyitah (2018) reveal that the students also agreed that the e-learning web-based module was easy to use.

From the findings, all interviewees in the study indicated that they have Wi-Fi connectivity in their homes thus making e-learning feasible. Parlakkiliç, Alaattin, (2015) support the point that facilities and resources available for adopting e-learning practices play an important role in determining e-learning readiness. The participants also highlighted that e-learning is not feasible due to a lack of infrastructure and resources. Respondents indicated that they do not have ICT gadgets. Due to a lack of infrastructure, a university cannot successfully implement e-learning (Basialia \& Kvavadze 2020). Respondents were in total agreement that the country is experiencing load shedding which is affecting the effective implementation of e-learning as ICT gadgets like smartphones and laptops need electricity. Data collected showed that lack of expertise in using ICT gadgets posed to be a challenge in the feasibility of e-learning as most students are not trained in computers. Some student teachers indicated that they were trained before the introduction of computers, and some of them had a negative attitude towards elearning. The country lags behind in the adoption, use and innovation of ICT, (Kachembere, 2011).

Findings on strategies for effective implementation revealed that there is a need for the provision of loan facilities repayable at low interest to buy smart devices as most of the student teachers are highly incapacitated as well as have access to reliable internet and infrastructure. Literature reviews indicate that most families in rural areas of the country do not own a computer or smartphone thus negatively impacting the whole online education (Basilaia \& Kvavadze, 2020). Hence stakeholders should collaborate and ensure that disadvantaged communities have solar boosters and generators. Network providers such as Econet, Netone or Telecel need to come up with services that will ensure the availability of cheap data bundles to students that e-learning becomes feasible. A report by Dzenga (2020) which outlines that the Ministry of Higher and Tertiary Education has partnered with mobile 
network providers to provide cheap data bundles for the students so that they gain access to the internet.

Respondents also indicated that some of the lecturers agreed to use WhatsApp instead of Google Classroom which is more costly and lecturers have extended due dates of assignments. This is in line with memos sent to students by HLIs such as Great Zimbabwe, Midlands State University, University of Zimbabwe and Harare Polytechnic on the extension of assignment due dates. Respondents disclosed that there is a need for online staff development and computer training to all students to ensure that they are well versed with technology for example on the use of Google classroom, E-registration, video conferencing, e-marking and feedback.

Findings also cited that students should be given an opportunity to iron out their concerns, give their views regarding e-learning and gain access to college online journals thus making e-learning feasible. Universities in the region should work hand in glove in giving suggestions on coping with the situation (Demayakor, 2020). Regarding the issue of face-toface lecturers, respondents indicated that HLIs should open institutions only when they have developed comprehensive health and safety strategies including social distancing, sanitization, provision of personal protective equipment as well as regular testing. This is in line with UNICEF and WHO (2020) which stipulates guidelines in relation to the opening of all schools in the midst of the pandemic. Stakeholders should do online follow-up with students to understand how COVID-19 has affected their experience and develop schemes to protect contracts.

\section{Conclusion and Suggestion}

Zimbabwean HLIs have adjusted to the new normal and embraced online learning to ensure the continuation of learning in the midst of the pandemic. Online learning overcomes educational obstacles and students will not only follow courses using the traditional method. Cost of education which includes commutation cost, stationary cost as well cost of buying hard copies is decreased and there is flexibility in participation in classes of all students. Many students perceive e-learning to be attractive and very effective. It widens students' experiences and expose them to the newest technologies. However, it is imperative to note that some students resist change, and stakeholders should help them adjust and embrace new learning methods instead of focusing on the dark cloud.

Based on the benefits of e-learning, perceptions of learners and challenges of e-learning in this study, educational stakeholders should ensure that learner's views and setbacks to elearning are considered such that e-learning develops to the fullest thus avoiding teething problems. Possible solutions such as the use of voice notes and soft copies, an extension of due dates, provision of cheap data bundles as well as the use of blended learning should be incorporated to ensure non-stop teaching. There is a need to select online applications that are effective and efficient to the implementation of online systems in HLIs. A multi-sectorial approach is needed in the provision of infrastructure, solar boosters as well as generators for 
effective implementation of e-learning. Provision of loans payable at low interest to students is uttermost importance. There is a need to ensure funding for the improvement of the education system and to provide capacity development training to stakeholders of HLIs. Further research is essential as well which will focus on the effects of blended approach/hybrid learning for students in HLIs in the midst of COVID-19 pandemic and perceptions of lecturers in HLIs towards e-learning amid COVID-19 pandemic.

\section{Conflict of Interest}

The authors declare no potential conflicts of interest with respect to the research, authorship and/or publication of this article.

\section{Funding}

The authors received no financial support for the research and authorship of this article.

\section{References}

Allo, M. D. G. (2020). Is the online learning good in the midst of Covid-19 Pandemic? The case of EFL learners. Journal Sinestesia, 10(1), 1-10.

Asogwa, C. I. "The challenges of optimizing E-learning opportunities for effective education service delivery in university of Nigeria Nsukka." Optimizing e-Learning Opportunities for Effective Education Service Delivery. Nsukka: Publication of Institute of Education University of Nigeria (2011).

Basilaia, G and Kvavadze, D. (2020). Transition to Online Education in Schools during a SARS-CoV-2 Coronavirus (COVID-19) Pandemic in Georgia. Pedagogical Research, 5(4), 2-9. https://doi.org/10.29333/pr/793 7

Bao, W. (2020). COVID -19 and online teaching in higher education: A case study of Peking University. Human Behavior and Emerging Technologies, 2(2), 113-115. https://doi.org/10.1002/hbe2.191

Braun, V., \& Clarke, V. (2006). Using thematic analysis in psychology. Qualitative Research in Psychology, 3(2), 77-101.

Chiromo, I. (2009) Research methods and statistics in Education: A students' Guide. Amodi Press. Mbambane.

Cohen, L., \& Manion, L. (2000). Research methods in education. Routledge. New York.

Creswell, J. (2012) Research Design, Qualitative and Quantitative Approaches, Sage Publication, USA.

Dzenga, L. (2020, April 3). COVID-19: What will happen to the academic calendar? The Herald Zimbabwe. Page 6.

Górska, D. (2016). E-learning in Higher Education. The Person and the Challenges. The Journal of Theology, Education, Canon Law and Social Studies Inspired by Pope John Paul II, 6(2), 35-43.

Demuyakor, J. (2020). Coronavirus (COVID-19) and Online Learning in Higher Institutions 
of Education: A Survey of the Perceptions of Ghanaian International Students in China. Online Journal of Communication and Media Technologies, 10(3), 2-9. https://doi.org/10.29333/ojcmt/8286

Harasim, L. M. (2017). Learning Theory and Online Technologies. Routledge.

Herald (2020). Zimbabwe Government Pushes for Online Education. https://www.chronicle.com/article/As-Coronavirus-Spreads-the/248200 (2020) as

Coronavirus Spreads, the Decision to Move Classes Online is the First Step.

Madi, I. (2015). A Study on Examining the Development of E-learning in Teacher Training and Professional Development at Nyadire Teachers' College: (Doctoral Dissertation) Bindura University of Science Education Faculty of education.

Issah, M. (2018). Change Leadership: The role of emotional intelligence. SAGE Open. https://doi.org/10.1177/2158244018800910

Natsai, A. and Mwayera, R. (2020). Education: Grounded by COVID-19. Retrieved from https://iafrican.com

Nagar, S. (2020). Assessing Students' Perception Toward e-learning and Effectiveness of Online Sessions Amid COVID-19 Lockdown Phase in India: An Analysis. UGC Care Journal, 19(13), 272-291.

Nziramasanga, C.T. (1999). 'Report of the Presidential Commission of Inquiry into Education and Training', Harare. Government Printers.

Popovici, A., \& Mironov, C. (2014). Students' perception on using eLearning technologies. Procedia - Social and Behavioral Sciences, 180, 1514 - 1519.

Sahu, P. (2020). Closure of Universities Due to Coronavirus Disease 2019 (COVID-19): Impact on Education and Mental Health of Students and Academic Staff. Cureus, 12(4), 2-6. DOI10.7759/cureus.7541.

Sintema, E. J. (2020). Effect of COVID-19 on the Performance of Grade 12 Students:

Implications for STEM Education. Eurasia Journal of Mathematics, Science and Technology Education, 16(7), 2-6. https://doi.org/10.29333/ejmste/7893

Smart, K.L. and Cappel, J.J. (2006), "Students' Perceptions of Online Learning: A Comparative Study". Journal of Information Technology Education: Research, 5(1), 201-219.

Tamrat, W., and Teferra, D. (2020). COVID-19 poses a serious threat to higher education. University World News, 9. Retrieved from https://www.universityworldnews.com/post.php?story=20200409103755715

Timmis, S., Broadfoot, P., Sutherland, R., and Oldfield, A. (2016). Rethinking assessment in a digital age: Opportunities, challenges and risks. British Educational Research Journal, 42(3), 454-476.

UNESCO. (2020). Global Education Coalition-290-million students out school due-COVID-

19. in UNESCO. https://en.unesco.org/news/290-million-students-out-school-duecovid-19-UNESCO-releases-first-global-numbers-and-mobilizes.

WHO. (2020). Report of the WHO-China Joint Mission on Coronavirus Disease 2019 (COVID- 19). WHO-China Joint Mission on Coronavirus Disease 2019, February, 1624. Retrieved from https://www.who.int/docs/default-source/coronaviruse/whochina-joint-mission-on-COVID-19-final-report.pdf 